\title{
Corporate governance practices' influence on customer loyalty in Nigerian retail banks
}

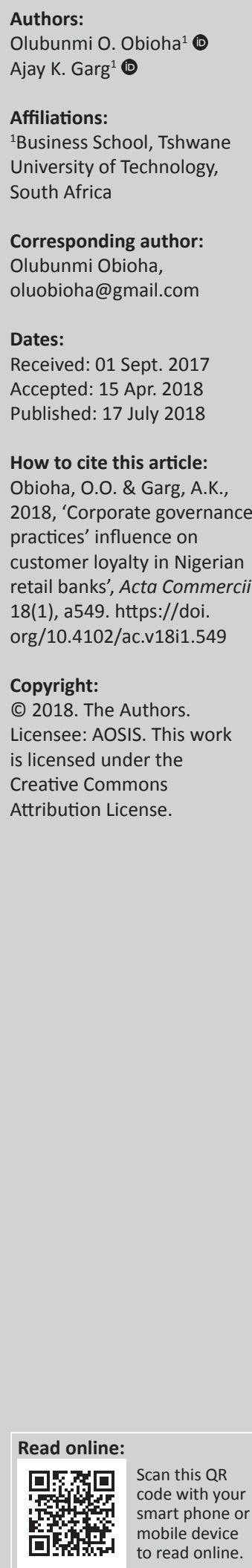

Orientation: Customer loyalty is crucial in the retail banking sector, given the increasing competition within the industry and from emerging non-traditional players.

Research purpose: This study sought to establish the influence of corporate governance practices on customer loyalty in Nigerian retail banks.

Motivation for the study: Conducting a study of this nature highlights how corporate governance practices contribute to customer loyalty in the retail banking sector of Nigeria as a developing country in Africa.

Research design, approach and method: Premised on relationship marketing and stakeholder theoretical orientations, the study used a sample of 424 bank customers scientifically selected from eight commercial banks identified within Ibadan Metropolis, Nigeria. A six-construct survey instrument was used to collect relevant data. Partial least square structural equation modelling (PLS-SEM) version 3 was utilised to ascertain the interaction between customer loyalty and corporate governance practices domains.

Main findings: The result of the PLS-SEM model established that all corporate governance practices had a positive effect on customer loyalty at a very significant level $(p<0.01)$, except transparency and disclosure, which had an inverse relationship and effect on customer loyalty, though at a non-significant level $(\beta=-0.005, p=0.93)$. Presence of competent bank management had the highest positive influence on customer loyalty.

Practical/managerial implications: The findings of this study will be useful for bank management and role players in the financial and other service sectors on the importance of good corporate governance and specific attributes of the identified corporate governance that are critical for business success.

Contribution/value-add: This study was able to identify corporate governance practices from customers' perspective, which is a departure from the traditional shareholder perspective in business studies. It has advanced the relatively known terrain in corporate governance and business literature by opening up new debates on the relevance of corporate leadership beyond the confines of the boardroom.

\section{Introduction}

Customer loyalty is recognised as crucial and an important outcome in marketing literature. Its role in the services industry in particular gains more prominence, because of the higher human involvement in comparison to goods (Rai \& Srivastava 2012). This acknowledgement resonates globally in the retail banking sector, which is characterised by serious rivalry amongst competitors and high customer expectations (Hafiz et al. 2015). Customers are becoming more knowledgeable and sophisticated in their approach to banking transactions, demanding greater flexibility, personal service and value.

The associated benefits from loyal customers include the likelihood to spend and buy more, positive word-of-mouth promotion and recommending of the service provider to other potential customers (Myftaraj \& Nexhipi 2014), which serve as a catalyst for sustainable growth and profit in the form of increased revenue and decreased costs. This recognition of benefits from longer customer tenure by businesses is what largely informed the evolution from transactional orientation to customer orientation, which focuses on building long-term relationship with customers or clients in the services industry (Hafiz et al. 2015). According to Taleghani et al. (2011), banking represents a service provider category with high interaction opportunities and customerservice provider employee contact. The customer is described as central to all marketing activities of banks the world over. Thus, customer loyalty and retention play a key role in the success of 
retail banks. Marketing literature suggests that customer experience is being prioritised as a way of obtaining competitive advantage, as opposed to the previous providerfocused position (Klaus \& Maklan 2013).

Thus, it has become pertinent for retail banks to have a good understanding of the drivers of customer loyalty so that proper marketing strategies can be formulated for long-term relationship building and also to secure opportunities for growth and increased profitability. Gummesson (1998) and Alrubaiee and Al-Nazer (2010) note that banks have undertaken several initiatives to enhance customer fidelity, such as implementing value chain analysis, customer satisfaction and loyalty programmes. This position has been validated in recent studies centred on broader service industry spectrum, particularly in the hospitality business (Gummesson 2014).

The Nigerian retail banking sector has undergone rapid changes in the last few years arising from reform policies set by government to address the debilitating state of banks, described as weak and fragile because of persistent illiquidity, unprofitable operations, poor asset base, gross insider abuse and poor corporate governance (Central Bank of Nigeria 2006; Ikeora, Igbodika \& Andabai 2016). This adverse development occurred in spite of the existence of two codes of corporate governance which aim to promote best practices in the private sector (Adekoya 2011). In 2003, the Securities and Exchange Commission (SEC) implemented the Code of Best Practices in Corporate Governance which was implemented for public-quoted companies, while the second, the Code of Corporate Governance for Banks, was established by the Central Bank of Nigeria after the consolidation exercise in 2006 (CBN 2006). However, in spite of these policy documents, corporate governance challenges in the banks persist.

The consequence of the reform that was implemented to address this situation was that banks had to either satisfy the requirement of a specified capital base, merge with other banks, be acquired by other healthy banks or face outright liquidation. This exercise placed structural pressure on the banking industry, especially in the area of retail banking in Nigeria, in addition to a general loss of confidence in the banking system by customers, demonstrated by increased activism and switching of banks in search of more reliable options. Given the general high involvement of customers in retail banks and the adverse effect of defection to the firm, it has become necessary for banks to move beyond the usual marketing factors or core activities and consider other potential factors that may impact on customer loyalty as a way to engender a long-term relationship with customers (Obioha 2017).

\section{Statement of the problem}

Given the importance of customer loyalty in retail banking, there is a need for further investigation into various facets, internally within the firm and externally, that may influence it or contribute to its enhancement. This study therefore examines the influence of corporate governance practices on customer loyalty in the retail banking sector in Nigeria. This investigation is hinged on the observation of the general loss of confidence in banks as a result of the instability in the banking sector occasioned by recurrent bank failures (Adeyemi 2011). The banking failure scenario and subsequent erosion of customer confidence suggest that there is a need to focus on factors that will engender customer loyalty issues beyond the usual marketing strategies adopted by banks, such as advertising and personal selling. This position is substantiated by Cronin, Brady and Hult (2000) who aver that retailers generally have little knowledge of the antecedents of customer loyalty. Also, Brady et al. (2005) argued that despite various studies focusing on drivers of loyalty, scholars as well as practitioners are still lacking in the understanding of loyalty determinants vis-à-vis corporate governance practices and their relative importance. There is no consensus amongst researchers on whether there are specific factors, especially those that are related to corporate governance practices in the banks, that influence customers' loyalty disposition. Several studies have investigated how relationship marketing, a discipline with a central focus on customers, enhances organisational performance (Bobalca 2014) and the effect of corporate governance on firm financial performance (Peters \& Bagshaw 2014). Despite these efforts by academics, little or no attention has been directed at the interaction between relationship marketing and corporate governance-related research. The selected corporate governance practices utilised in this study are indeed those that are in the public domain, observed by the customers and therefore not the traditionally highly sensitive issues that are basically known by the bank role players alone. Empirical evidence is therefore needed to better understand how these corporate governance practices individually and collectively influence customer loyalty in Nigeria retail banks.

\section{Research objectives}

To investigate the relative interactive influence of corporate governance practices ${ }^{1}$ on customer loyalty dispositions to banks.

\section{Research hypotheses}

Hypothesis 1: The presence of bank management with integrity has a positive significant influence on customer loyalty.

Hypothesis 2: The presence of competent bank management has a positive significant influence on customer loyalty.

Hypothesis 3: Transparency and disclosure of information by banks has positive significant influence on customer loyalty.

Hypothesis 4: The presence of a customer complaints management system has a positive significant influence on customer loyalty.

Hypothesis 5: Banks' corporate reputation has a positive significant influence on customer loyalty.

1.Corporate governance practices are the presence of bank management with integrity, competent bank management, transparency and disclosure of information, a customer complaint management system and corporate reputation. 


\section{Literature review}

\section{Corporate governance practices and mechanisms}

Corporate governance is a system or an arrangement that comprises a wide range of practices (accounting standards, rules concerning financial disclosure, executive compensation, size and composition of corporate boards) and institutions (legal, economic and social) that protect the interest of the corporation's owners (Obiyo \& Torbira 2011). Literature suggests that, over the years, globalisation has substantially facilitated the evolution of best practices amongst corporations and countries. The intense competition amongst firms in international markets has necessitated the drive to update corporate governance practices on a regular basis, with the aim of attaining high-quality corporate governance standards.

Existing literature on banks' corporate governance has focused on various practices and mechanisms to evaluate a corporation's performance. These include how board composition affects performance, as well as to which extent board characteristics (diversity, external ties, and so on) affect a firm's competitiveness and performance (Rashid 2018). Furthermore, Shen and Chih (2007) investigated corporate governance scores for Asian firms using characteristics that include management discipline, transparency, independence, accountability, responsibility, fairness and social awareness.

Other studies investigated to which extent board size, the director's experience and other activities affect the performance (Mehran 1995; Muchemwa, Padia \& Callaghan 2016). The performance measures varied from profit margins, expected stock returns, firm valuation to market valuation (Black, Jang \& Kim 2006; Choudhary 2015). The variables for this study are obtained from an analysis of the Nigerian Code of Best Practices (2003), the Code on Corporate Governance for Banks (2006) and from previous empirical studies on corporate governance.

As the focus of this study is on customer loyalty, five main corporate governance indicators were identified to be relevant to this study, namely integrity of leadership, competence of leadership, transparency and disclosure of information, a complaints management system and corporate reputation or image. These five corporate governance practices identified were chosen based on the weight of research suggesting their importance to organisational or institutional performance and their relevance to customers. (Esmaeilpour \& Barjoei 2016; Ghazizadeh et al. 2010; Gladson 2007; Kim \& Brymer 2011).

\section{Integrity of leadership}

Empirical studies highlight the notion that corporate governance has a leadership dimension, as it provides directional leadership to organisations by creating an enabling environment that integrates and systematises various collaborative efforts for setting objectives and achieving corporate goals (Fama \& Jensen 1983; Ogbechie \&
Koufopolous 2010). Boards of directors and senior management represent leadership of any organisation and consequently have the ultimate internal authority within a company, and they play a key role in the overall overseeing of the company, especially monitoring top management (Chatterjee et al. 2003).

\section{Competence of leadership}

Competence of leadership is recognised as one of the key characteristics of a good leader. A competent leader has the ability to solve complex issues and to make good decisions that will increase efficiency and effectiveness in an organisation (Jones \& George 2003). Acting in their capacity as leaders, the board of directors is expected to bring specialised expertise and a wealth of knowledge to the company (Weir \& Lang 2001). Given the opacity and complexity that characterise financial institutions, it has become pertinent for a board of directors to understand the inner workings of the bank in order to discharge their functions effectively.

\section{Transparency and disclosure of information}

Transparency of financial information is very crucial in a firm's operations, relationship with other stakeholders and sustainability. Accordingly, transparency and disclosure of information are widely considered key elements of good corporate governance in banks (Hawley 1996; Ngerebo \& Sweneme 2012). They are described as important pillars of a corporate governance framework that enable adequate information flow to various stakeholders. As such, stakeholders are provided with the necessary information to judge whether their interests are being taken care of, or not, which helps them decide on their investments or other interests (Sanusi 2002).

\section{Customer complaint management and dispute resolution}

Another aspect of corporate governance practices is evidenced in the manner in which the complaint management system, which is part of the redress mechanism expected to be in place in banks, is structured and managed. Generally, customers lodge complaints from time to time when they perceive that the bank has acted unethically or inappropriately in handling their affairs. This may arise because of excess charges, unauthorised deductions, dishonoured cheques, non-disclosure of terms and conditions, foreign remittance, automated teller machine (ATM) fraud and related matters (Obioha 2017).

\section{Corporate reputation and image}

Corporate reputation has been identified as one of the drivers of corporate governance. It is also acknowledged as having the potential to impact on customer loyalty towards the firm (Nguyen \& Leblanc 2001). Corporate reputation is defined as a 'collective assessment of a company's ability to provide valued outcomes to a representative group of stakeholders' (Fombrun, Galdberg \& Sever 2000). 


\section{Customer loyalty in the banking industry}

According to Taleghani et al. (2011), banking represents a service provider category with high interaction opportunities and customer-service provider employee contact. The customer is described as central to all marketing activities of banks the world over. Thus, customer loyalty and retention play a key role in the success of retail banks. Bank loyalty is defined as the:

biased (non-random) behavioural response (revisit), expressed over a period of time by some decision-making unit with respect to one bank out of a set of banks, which is a psychological function (decision-making and evaluative process resulting in brand commitment. (Bloemer et al. 1998:277)

Loyalty can also be described as a strongly held commitment to a bank in a manner that the customer desires to patronise and buy products consistently without resorting to switching factors and marketing appeals (Oliver 1999). Studies have highlighted three reasons why loyalty is a particularly important issue for service providers like banks. Firstly, loyalty is greater or more prevalent amongst services consumers than goods consumers. Secondly, services provide more opportunities for person-to-person interactions. This, in turn, often provides opportunities for loyalty to develop and perceived risk is often greater when purchasing services than goods (Parasuraman, Zeithaml \& Berry 1985; Suprenant \& Solomon 1987; Zeithaml 1981).

Therefore, it becomes necessary for bank management to carefully consider the factors that might increase customer loyalty and retention rates. Ghazizadeh et al. (2010) assert that, to achieve this goal, banks have to adopt a marketorientation approach that identifies consumer needs, designs new products or services and redesigns the old ones. Gummesson (1998) notes that banks have undertaken several initiatives, such as value chain analysis, customer satisfaction and loyalty programmes. Also included in these factors is minimising switching behaviour, perceived service quality, satisfaction, trust and switching costs amongst others (Afsar et al. 2010; Petruzzellis, Romanazzi \& Gurrieri 2009). In the context of Nigeria, the occurrence of banking failures and the loss of confidence expressed by customers necessitate a move away from the usual drivers of customer loyalty and a consideration of corporate governance dimensions as potential drivers of enhancing bank-customer relationships.

\section{Research methodology Study population and sample}

The target population for this study were customers of the existing 22 retail banks located in Ibadan, one of the capital cities in Nigeria, as at the time of this study (2014-2016). Eight banks were purposively chosen from strata of categories of banks identified. In order to bring a more robust analysis, the selected banks were categorised into two distinct groups, namely banks by merger experience and bank by generation category. Three banks that have merger ${ }^{2}$ experience within the past six years and five from those that have no merger $^{3}$ or acquisition history within the same period were chosen. The bank generation categorisation was based on the length of time in the business of banking and the extent that modern technology is used in banking operations. A quota sampling technique was applied in a distributive manner to select 62 respondents from each bank. As the universe of the target population (bank customers) was not known, the sample from each bank was determined through convenience process. In this case, the parameters set by the researcher upon which participants were deemed selectable were considered. Thus, a total sample of 496 respondents affiliated to the eight banks were used for this study. The selection criteria for the sample were individuals who had a bank account maintained for at least 1 month, with the ability to read and write. At the end of the data collection, 424 questionnaires were found complete and usable for the analysis, which represented an $85 \%$ response rate. A total of 424 bank customers were conveniently selected, in which process respondents' social categories were taken into consideration.

\section{Data collection procedure}

A survey (questionnaire) was administered to a sample of 424 bank customers selected from eight purposively chosen retail banks. A four-point Likert scale was used where respondents were asked to 'Strongly Agree', 'Agree', 'Disagree' or 'Strongly Disagree' with statements (items) referring to customers' disposition to being loyal to their respective banks. Loyalty as a construct contained nine items that measure it. Similarly, the five corporate governance practices domains contain sets of indicators that measured each of them. The fourpoint Likert scale employed in the questionnaire was to avoid the tendency to swing to ambivalence by the respondents.

\section{Data analysis}

Data collected were analysed by the use of Statistical Package for Social Sciences (SPSS) tools. The reliability test produced a Cronbach's alpha coefficient of 0.95 (pretest) and 0.87 (final analysis) for the customer loyalty construct. The final data analysis began with a reliability test of the constructs and items to ascertain the suitability of the final research instrument. Based on the acceptable benchmark value of average intra-class correlation of $>0.30$ and Cronbach's alpha $\geq 0.70$ for scale reliability, the result of the test shows that all the five constructs (domains) have acceptable and high reliability with values ranging from 0.87 to 0.89 . The order of their strength of reliability based on Cronbach's alpha coefficient from the highest to the lowest was as follows: presence of bank management with integrity (0.89), transparency and adequate disclosure (0.87), corporate reputation (0.88), presence of competent bank management (0.87) and presence of customer complaint and dispute resolution system (0.89). Further analysis of data to capture Trust Bank Plc, United Bank for Africa (UBA) PIc, Union Bank PIc and Zenith Bank PIc. 
the objectives of this study was performed by use of multiplicity of statistical tools, including partial least square structural equation model (PLS-SEM) Smart PLS (version 3). ${ }^{4}$ This was utilised to ascertain the influence of corporate governance practices domains on customer loyalty, with Pearson's correlation moment analysis as a complementary tool to establish the association between corporate governance practices and customer loyalty.

Equation estimation formula (Partial least square structural equation model):

$$
\begin{aligned}
& \eta_{(m \times 1)}=B_{(m \times m)} \times \xi_{(n \times 1)}+\Gamma_{(m \times 1)} \times \xi_{(n \times 1)}+\zeta_{(m \times 1)} \\
& y_{(p \times 1)}=\Lambda_{y(p \times m)} \times \eta_{(m \times 1)}+\xi_{(p \times 1)} \\
& X_{(q \times 1)}=\Lambda_{x(q \times n)} \times \xi_{(n \times 1)}+\delta_{(q \times 1)}
\end{aligned}
$$

where $\eta$ is the latent endogenous construct associated with observed $y$ indicators, $B$ is the regression of one endogenous construct on another endogenous construct, $\xi$ is the latent exogenous construct associated with observed $x$ indicators, $\zeta$ is the error term associated with formative construct, $\varepsilon$ is the error term associated with $y$ indicators and $\delta$ is the error term associated with $x$ indicators.

Equation estimation formula (Pearson's correlation moment, $r$ ):

$$
r=\frac{n\left(\sum x y\right)-\left(\sum x\right)-\left(\sum y\right)}{\sqrt{\left[n\left(\sum x^{2}\right)-\left(\sum x^{2}\right)\right]\left[n\left(\sum y^{2}\right)-\left(\sum y^{2}\right)\right]}}
$$

where $n$ is the number of pairs of scores, $\sum x y$ is the sum of the products of paired scores, $\sum x$ is the sum of $x$ scores, $\sum y$ is the sum of $y$ scores, $\sum x^{2}$ is the sum of squared $x$ scores and $\sum y^{2}$ is the sum of squared $y$ scores.

\section{Ethical considerations}

This study strictly adhered to all the ethical prescripts of the host institution, Tshwane University of Technology, and related human science ethical issues by subjecting this research to the entire process. The designated departmental, faculty and university central committees approved the research; having met the ethical requirements a Clearance Certificate (Ref \#: FREC2016/FR/04/001-MS) was issued to the researcher by the Faculty of Management Sciences Research Ethics Committee of the university. The participants' informed consent was received and their confidentiality and privacy observed by the researcher.

4.The PLS-SEM allows the use of larger sample size, provided that a large number of indicator variables are used to measure constructs (Hair, Ringle \& Sarstedt 2011). There is a 10 times rule of thumb provided as a guideline for minimum sample size as follows: The larger of (1) 10 times the largest number of formative indicators used to measure one construct or (2) 10 times the largest number of structural path directed at a particular latent construct in the structural model (Hair et al. 2017) Any sample size of less than 100 is considered appropriate for a complex structura model, like the one used in this study. Thus, a sample size of 424 is within the acceptable size in PLS-SEM. According to Hair et al. (2017), larger sample sizes used in PLS-SEM increases precision (i.e. consistency) of PLS-SEM estimations.

\section{Presentation of results and interpretation \\ Corporate governance practices and customer loyalty nexus}

In this study, the researcher sought to establish the effects of various corporate governance practices on customer loyalty to banks. This is with the aim to determine the strength of the effects of each corporate governance practice (domain), as individual components and the relative strengths comparatively. The major questions in this regard were: What is the strength of the effect of each of the corporate governance domains on customer loyalty? What is the relative strength of each of the domains? Which corporate governance domain is likely to have the highest influence on customer loyalty in the banks?

Table 1 shows the estimates of model fitness and quality indices of the constructs and indicators included in the test of the interaction between customer loyalty and corporate governance practices, as generated by PLS-SEM version 3 . This interactive model met the standard requirement by the PLS-SEM version 3 for evaluating the reflective measurement model for the latent construct, customer loyalty (Custloyl).

The average variance extracted (AVE) of $0.498(T=14.200$, $p=0.00)$, approximately 0.50 , indicated is acceptable. The AVE is a metric to assess the communality of a construct. An AVE estimate of 0.50 or higher indicates that, on average, the construct, customer loyalty (Custloyl), explains more than half of the variance of its indicators' convergent validity (Hair et al. 2017), which is the acceptable standard. Values below 0.50 are unacceptable. Also, the $R$-squared value of the endogenous latent variable, customer loyalty (Custloyl) $0.531(T=15.618, p=0.00)$, establishes convergent validity. This indicates that the five constructs, namely presence of management with integrity (Preintegr), presence of competent bank management (Precompt), transparency (Transpar), presence of a complaints management system (Precompl) and corporate reputation (Corprepu), explain $53.1 \%$ of the variance of the endogenous variable, namely customer loyalty (Custloyl). Lastly, the Cronbach's alpha (0.865 for customer loyalty) was above the 0.70 upper higher acceptable threshold, establishing construct reliability and validity.

The internal consistency reliability of the indicator variables for the customer loyalty construct (Custloyl), measured by Cronbach's alpha, ranges between 0.79 to 0.87 , which is regarded as satisfactory in social science research (Hair et al. 2017). Also, the internal consistency of the indicator (0.895) is established, because this value was above the threshold of 0.70 , considered the standard (Hair et al. 2017). The outer loadings for each of the indicators on the customer loyalty construct indicate values ranging from 0.40 to 0.85 . This was considered sufficient, because they contribute to the convergent validity of the endogenous construct, customer loyalty (Custloyl) (Hair et al. 2017:114). In establishing convergent validity, indicators with very low 
TABLE 1: Model fitness and quality indices.

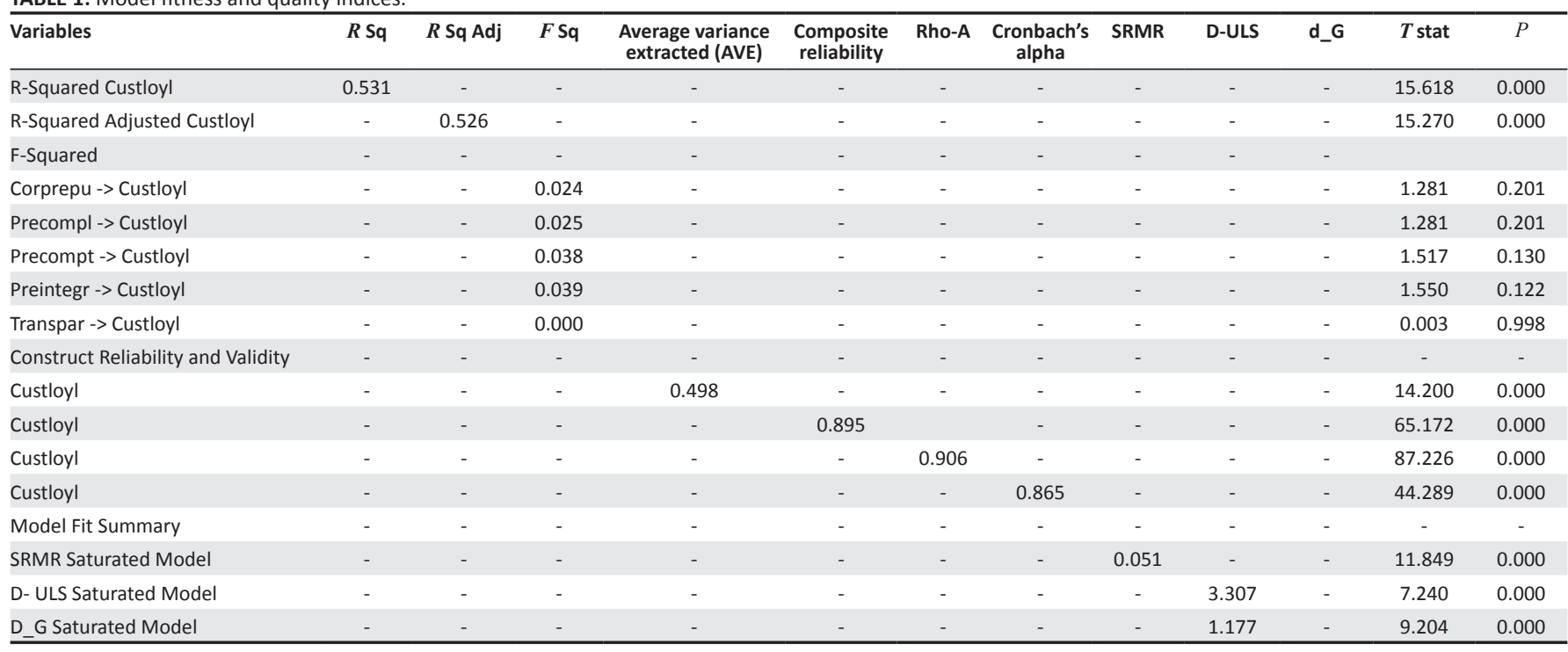

*, Significant at $p \leq 0.05$

outer loadings (below 0.40) are considered weak and are therefore recommended to be eliminated from the construct (Bagozzi \& Philipps 1991; Hair et al. 2011). Considering the strength of various corporate governance domains' effects on customer loyalty, Figure 1 and specifically Table 2 show the total effect the domains had on customer loyalty.

\section{Presence of bank management with integrity and customer loyalty nexus}

Hypothesis 1: The presence of bank management with integrity has a positive significant influence on customer loyalty.

The result of this analysis shows that presence of bank management with integrity had a significant positive effect $(\beta=0.220)$ and $T$-value (3.557) at $p=0.00$ significant level on customer loyalty.

Considering the association and covariance between customer loyalty and bank management with integrity attributes, a positive relationship at significant level of $p=0.00$ was found (Table 3 ). This result further confirmed the importance of these attributes in increasing customer loyalty to their banks. Bank management and staff's level of assistance to customers was the most important attribute in this regard, while the attribute of bank management saying what they mean (being straightforward) in their transactions with customers had the least association in comparison with other attributes. As management integrity attributes increased collectively or individually, so did customer loyalty in the same direction.

\section{Presence of competent bank management and customer loyalty nexus}

Hypothesis 2: The presence of competent bank management has a positive significant influence on customer loyalty.
The presence of competent management was found to have a positive total effect of $\beta=0.228$ at a significant level of $p=0.00$ on customer loyalty.

Further testing (Table 4) of relationship between customer loyalty and all the attributes of competent bank management revealed significant positive relationship between them. Responding to customer banking needs was found to be highly associated with customer loyalty, followed by promotion of excellent banking services. On the other hand, experience or knowledge in banking by the management team and clear vision in banking were the lowest ranking attributes of competency in banking associated with customer loyalty.

\section{Transparency and disclosure on customer loyalty nexus}

Hypothesis 3: Transparency and disclosure of information by banks has positive significant influence on customer loyalty.

In the present study, the transparency or disclosure domain of corporate governance practices was found to negatively affect bank customers' loyalty. The total effect $(\beta=-0.005$, $p=0.93$ ) means that the effect of transparency or disclosure was very little in terms of what it contributes to customer loyalty.

The cross-loading result (Table 5) of the covariance between customer loyalty and the attributes of transparency or disclosure domain confirmed that customers' accessibility to bank officials had the highest strength of correlation or association $(r=0.432)$ with customer loyalty, compared to other attributes. Banks' provision of information on their contribution to the community had the weakest link to customer loyalty $(r=0.101)$. 


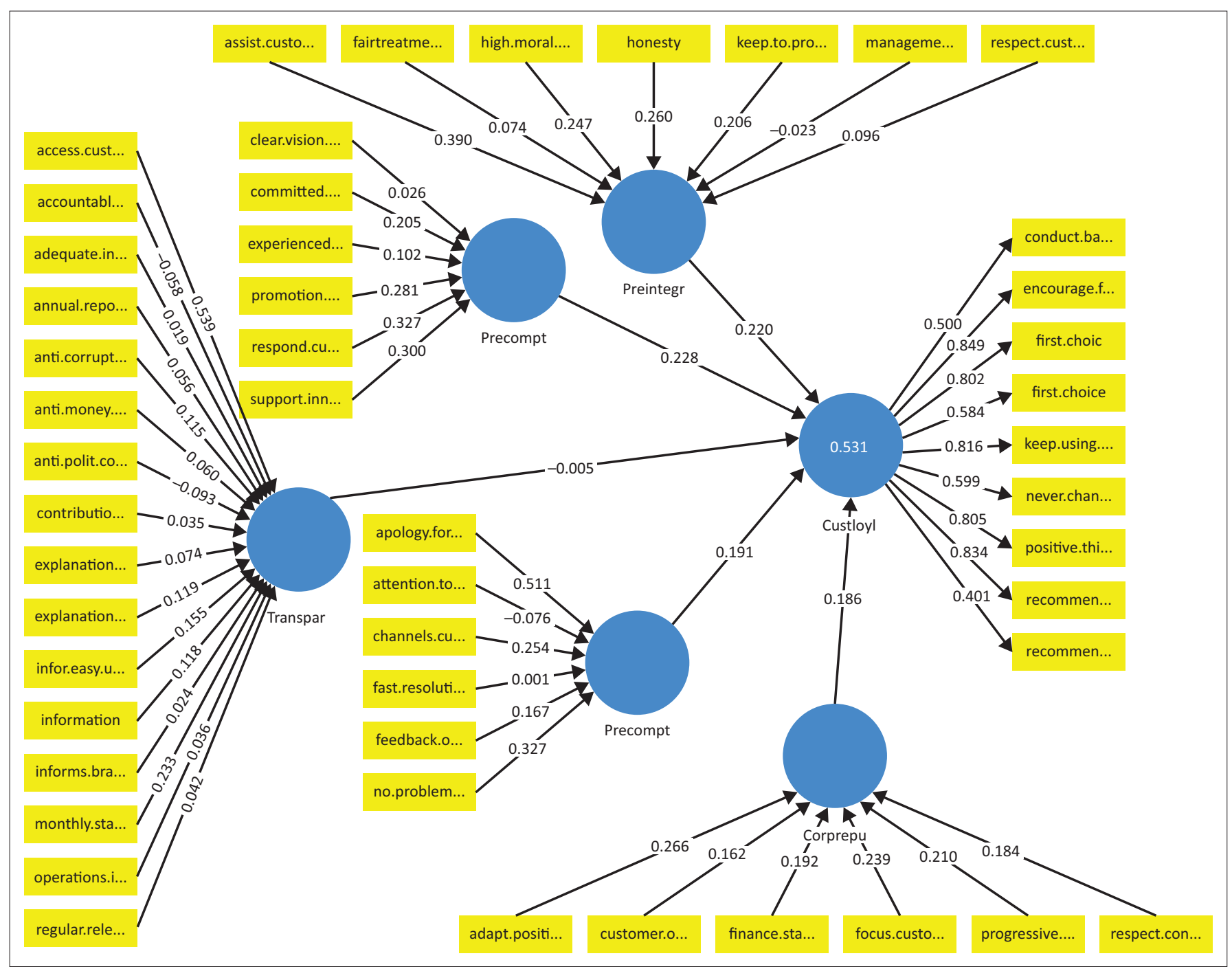

Key: Variables

Integrity/Preintegr: Presence of bank management with integrity

Competent/Precompt: Presence of competent bank management

Transparency/Transpar: Transparency and disclosure

Complaint.sys/Precompl: Presence of a customer complaint management system

Reputation/Corprepu: Corporate reputation

FIGURE 1: Partial least square structural equation model indicating the influence of corporate governance practices on customer loyalty.

TABLE 2: Path coefficients and total effects.

\begin{tabular}{lcccc}
\hline FACTORS & Path coefficients & Total effects & $\boldsymbol{T}$ statistics & $\boldsymbol{P}$ \\
\hline Corprepu $->$ Custloyl & 0.186 & 0.186 & 2.901 & $0.004^{*}$ \\
Precompl -> Custloyl & 0.191 & 0.191 & 2.754 & $0.006 *$ \\
Precompt -> Custloyl & 0.228 & 0.228 & 3.317 & $0.001^{*}$ \\
Preintegr -> Custloyl & 0.220 & 0.220 & 3.557 & $0.000^{*}$ \\
Transpar -> Custloyl & -0.005 & -0.005 & 0.080 & 0.936 \\
\hline
\end{tabular}

*, Significant at $p \leq 0.05$.

\section{Customer complaint management on customer loyalty nexus}

Hypothesis 4: The presence of a customer complaints management system has a positive significant influence on customer loyalty.

The extent to which a customer complaint management system influenced or affected customer loyalty was explained in this study. The study found that a customer complaints management system in banks had a positive and significant effect on customer loyalty $(\beta=0.191, p=0.00)$.

Further analysis of correlation of covariance (Table 6) between attributes of the complaint management system and customer loyalty confirmed apology for complaints by bank management and officials as the highest attribute of complaint management, while fast resolution of complaints was found to be least associated with customer loyalty to banks. However, all the attributes of the customer complaint system were positively associated with customer loyalty at a significant level.

\section{Corporate reputation and customer loyalty nexus}

Hypothesis 5: Banks' corporate reputation has a positive significant influence on customer loyalty.

This study tested and found that corporate reputation garnered by banks over time positively affected customer 
TABLE 3: Cross-loadings (correlations) of the presence of bank management attributes with integrity on customer loyalty.

\begin{tabular}{|c|c|c|c|c|c|c|}
\hline $\begin{array}{l}\text { Bank Management with } \\
\text { Integrity Attributes }\end{array}$ & $\begin{array}{l}\text { Corporate } \\
\text { reputation }\end{array}$ & $\begin{array}{l}\text { Customer } \\
\text { loyalty }\end{array}$ & $\begin{array}{c}\text { Presence of complaint } \\
\text { management }\end{array}$ & $\begin{array}{c}\text { Presence of competent } \\
\text { management }\end{array}$ & $\begin{array}{l}\text { Presence of } \\
\text { integrity }\end{array}$ & $\begin{array}{c}\text { Transparency and } \\
\text { disclosure }\end{array}$ \\
\hline assist.customers & 0.556 & $0.559 *$ & 0.614 & 0.633 & 0.867 & 0.490 \\
\hline fairtreatment.to.customers & 0.541 & $0.442^{*}$ & 0.541 & 0.573 & 0.685 & 0.464 \\
\hline honesty & 0.531 & $0.506^{*}$ & 0.517 & 0.511 & 0.783 & 0.429 \\
\hline keep.to.promises & 0.516 & $0.508^{*}$ & 0.589 & 0.592 & 0.787 & 0.446 \\
\hline management.say.mean & 0.513 & $0.418 *$ & 0.532 & 0.548 & 0.648 & 0.463 \\
\hline
\end{tabular}

$*, r$ coefficient significant at $p \leq 0.05$.

TABLE 4: Cross-loadings (correlation) of the presence of competent bank management attributes on customer loyalty.

\begin{tabular}{|c|c|c|c|c|c|c|}
\hline $\begin{array}{l}\text { Competent bank } \\
\text { management attributes }\end{array}$ & $\begin{array}{l}\text { Corporate } \\
\text { reputation }\end{array}$ & Customer loyalty & $\begin{array}{l}\text { Presence of complaint } \\
\text { management }\end{array}$ & $\begin{array}{l}\text { Presence of competent } \\
\text { management }\end{array}$ & $\begin{array}{l}\text { Presence of } \\
\text { integrity }\end{array}$ & $\begin{array}{l}\text { Transparency and } \\
\text { disclosure }\end{array}$ \\
\hline clear.vision.banking & 0.576 & $0.419 *$ & 0.532 & 0.639 & 0.601 & 0.462 \\
\hline committed.to.problem.solving & 0.603 & $0.521 *$ & 0.657 & 0.794 & 0.639 & 0.550 \\
\hline experienced.in.banking & 0.508 & $0.395^{*}$ & 0.465 & 0.602 & 0.498 & 0.430 \\
\hline promotion.excellent.service & 0.591 & $0.560 *$ & 0.567 & 0.854 & 0.600 & 0.559 \\
\hline respond.customer.needs & 0.601 & $0.565^{*}$ & 0.640 & 0.861 & 0.622 & 0.568 \\
\hline support.innovation & 0.570 & $0.521 *$ & 0.471 & 0.795 & 0.550 & 0.434 \\
\hline
\end{tabular}

$*, r$ coefficient significant at $p \leq 0.05$.

TABLE 5: Cross-loadings (correlations) of transparency and disclosure attributes on customer loyalty.

\begin{tabular}{|c|c|c|c|c|c|c|}
\hline $\begin{array}{l}\text { Transparency and } \\
\text { disclosure attributes }\end{array}$ & $\begin{array}{l}\text { Corporate } \\
\text { reputation }\end{array}$ & $\begin{array}{c}\text { Customer } \\
\text { loyalty }\end{array}$ & $\begin{array}{c}\text { Presence of complaint } \\
\text { management }\end{array}$ & $\begin{array}{c}\text { Presence of competent } \\
\text { management }\end{array}$ & $\begin{array}{c}\text { Presence of } \\
\text { integrity }\end{array}$ & $\begin{array}{c}\text { Transparency and } \\
\text { disclosure }\end{array}$ \\
\hline informs.branches.public & 0.245 & 0.209 & 0.258 & 0.225 & 0.201 & 0.403 \\
\hline access.customers & 0.537 & $0.432 *$ & 0.594 & 0.571 & 0.470 & 0.835 \\
\hline accountable.ownership.shares & 0.226 & 0.138 & 0.279 & 0.189 & 0.185 & 0.267 \\
\hline $\begin{array}{l}\text { adequate.information. } \\
\text { bankproducts }\end{array}$ & 0.302 & 0.199 & 0.345 & 0.261 & 0.296 & 0.385 \\
\hline annual.reports.avail.public & 0.379 & $0.256^{*}$ & 0.347 & 0.327 & 0.312 & 0.495 \\
\hline anti.money.laundering & 0.308 & 0.211 & 0.338 & 0.272 & 0.228 & 0.407 \\
\hline anti.polit.contributions & 0.281 & 0.200 & 0.337 & 0.279 & 0.284 & 0.385 \\
\hline contributions.community & 0.118 & 0.101 & 0.095 & 0.104 & 0.092 & 0.194 \\
\hline explanation.products & 0.499 & $0.351 *$ & 0.490 & 0.459 & 0.427 & 0.678 \\
\hline explanation.services & 0.505 & $0.349 *$ & 0.499 & 0.457 & 0.398 & 0.673 \\
\hline infor.easy.understand & 0.424 & $0.342 *$ & 0.393 & 0.401 & 0.400 & 0.659 \\
\hline information & 0.336 & $0.236^{*}$ & 0.354 & 0.275 & 0.293 & 0.456 \\
\hline operations.international.public & 0.331 & $0.237^{*}$ & 0.318 & 0.313 & 0.281 & 0.457 \\
\hline regular.release.ann.reports & 0.394 & $0.230 *$ & 0.317 & 0.322 & 0.274 & 0.444 \\
\hline
\end{tabular}

$*, r$ coefficient significant at $p \leq 0.05$.

loyalty to the bank $(\beta=0.186, p=0.00)$. As such, customers' loyalty to their bank increased as customers recognise or are aware of bank officials and management's reputation.

The study further tested the correlation between corporate reputation attributes and customer loyalty. The results (Table 7) confirmed that while all the attributes of corporate reputation are positively and significantly associated with customer loyalty to banks, banks' adaptability to positive changes and financial stability were found to have the strongest and least link with it, respectively. This means that banks' adaptability to positive changes in the industry increases customers' loyalty to their banks.

\section{Correlation between corporate governance practices domains and customer loyalty}

In estimating the correlation between customer loyalty and the corporate governance practices (domains), Table 8 revealed that while all corporate governance practices (domains) had a positive association with customer loyalty at a very significant level, presence of competent bank management has the highest association with customer loyalty $(r=0.612, p=0.00)$. This is followed by corporate reputation and customer loyalty $(r=0.592, p=0.00)$ and the presence of bank management with integrity with customer loyalty $(r=0.59, p=0.00)$. Transparency and disclosure was found to be least associated with customer loyalty $(r=0.403$, $p=0.00$ ) when compared with other corporate governance practices (domains). This result implies that customer loyalty increases as each of the corporate governance practices (domains) increases, especially with the presence of competent bank management.

\section{Discussion of findings}

This study tested and supported or unsupported the five research hypotheses that were set at the beginning of the study. The summary of the outcome of the tests of hypotheses is presented in Table 9 . 
TABLE 6: Cross-loadings (correlations) of complaint management system attributes on customer loyalty.

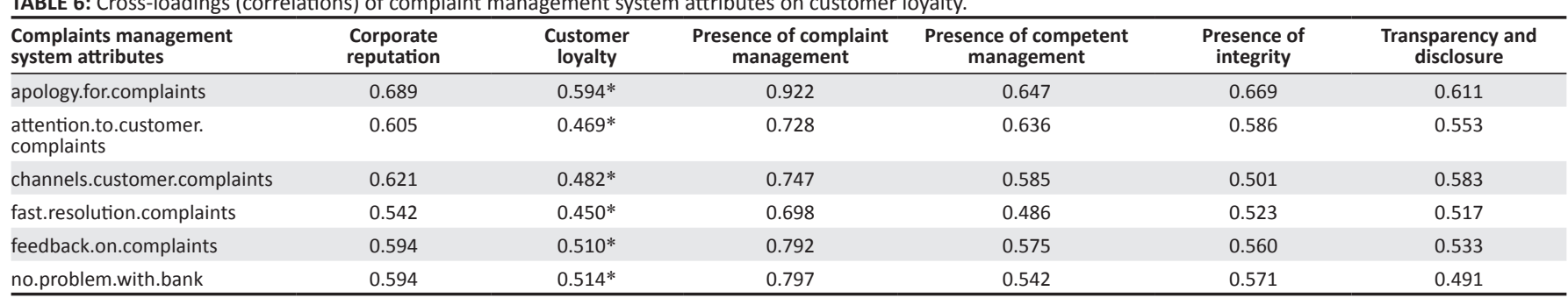

$*, r$ coefficient significant at $p \leq 0.05$.

TABLE 7: Cross-loadings (correlations) of bank corporate reputation attributes on customer loyalty.

\begin{tabular}{|c|c|c|c|c|c|c|}
\hline Corporate reputation & $\begin{array}{l}\text { Corporate } \\
\text { reputation }\end{array}$ & $\begin{array}{l}\text { Customer } \\
\text { loyalty }\end{array}$ & $\begin{array}{c}\text { Presence of complaint } \\
\text { management }\end{array}$ & $\begin{array}{c}\text { Presence of competent } \\
\text { management }\end{array}$ & $\begin{array}{c}\text { Presence of } \\
\text { integrity }\end{array}$ & $\begin{array}{c}\text { Transparency and } \\
\text { disclosure }\end{array}$ \\
\hline adapt.positive.change & 0.853 & $0.547^{*}$ & 0.608 & 0.594 & 0.556 & 0.571 \\
\hline customer.oriented & 0.830 & $0.532 *$ & 0.673 & 0.622 & 0.540 & 0.622 \\
\hline finance.stability & 0.679 & $0.435^{*}$ & 0.478 & 0.452 & 0.448 & 0.375 \\
\hline focus.customer.needs & 0.827 & $0.531^{*}$ & 0.672 & 0.615 & 0.591 & 0.539 \\
\hline progressive.innovative & 0.824 & $0.529 *$ & 0.576 & 0.600 & 0.524 & 0.544 \\
\hline respect.considerate.customers & 0.752 & $0.482 *$ & 0.622 & 0.574 & 0.577 & 0.521 \\
\hline
\end{tabular}

$*, r$ coefficient significant at $p \leq 0.05$.

TABLE 8: Pearson's correlation between customer loyalty and corporate governance practices (domains).

\begin{tabular}{lcccccc}
\hline Variables & $X_{1}$ & $X_{2}$ & $X_{3}$ & $X_{4}$ & $X_{5}$ & $X_{6}$ \\
\hline Cust.loyl $\left(X_{1}\right)$ & 1.000 & - & - & - & - & - \\
& $(0.000)$ & & & & & - \\
Integrity $\left(X_{2}\right)$ & $0.590 * *$ & 1.000 & - & - & - & - \\
& $(0.000)$ & $(0.000)$ & & & & - \\
Competent $\left(X_{3}\right)$ & $0.612 * *$ & $0.784 * *$ & 1.000 & - & - & - \\
& $(0.000)$ & $(0.000)$ & $(0.000)$ & & & - \\
Transparency $\left(X_{4}\right)$ & $0.403 * *$ & $0.536 * *$ & $0.556 * *$ & 1.000 & - & - \\
& $(0.000)$ & $(0.000)$ & $(0.000)$ & $(0.000)$ & & \\
Complaint.sys $\left(X_{5}\right)$ & $0.585 * *$ & $0.711 * *$ & $0.722 * *$ & $0.588^{* *}$ & 1.000 & - \\
& $(0.000)$ & $(0.000)$ & $(0.000)$ & $(0.000)$ & $(0.000)$ & \\
Reputation $\left(X_{6}\right)$ & $0.592^{* *}$ & $0.692 * *$ & $0.743 * *$ & $0.585 * *$ & $0.754 * *$ & 1.000 \\
& $(0.000)$ & $(0.000)$ & $(0.000)$ & $(0.000)$ & $(0.000)$ & $(0.000)$ \\
\hline
\end{tabular}

${ }^{*}, r$ coefficient correlation significant at 0.05 (2-tailed); ${ }^{* *}, r$ coefficient correlation significant at 0.01 (2-tailed)

\section{TABLE 9: Summary of test of hypotheses.}

\begin{tabular}{ll}
\hline Hypotheses & Result \\
\hline $\mathrm{H}_{1}:$ The presence of Bank Management with Integrity has a positive & Supported \\
significant influence on Customer Loyalty & \\
$\mathrm{H}_{2}:$ The presence of Competent Bank Management has a positive & Supported \\
significant influence on Customer Loyalty & \\
$\mathrm{H}_{3}:$ Transparency and Disclosure of Information by banks has a & Unsupported \\
positive significant influence on Customer Loyalty & \\
$\mathrm{H}_{4}:$ The presence of a Customer Complaints Management System & Supported \\
has a positive significant influence on Customer Loyalty & \\
$\mathrm{H}_{5}:$ Bank's Corporate Reputation has a positive significant influence & Supported \\
on Customer Loyalty & \\
\hline
\end{tabular}

The result of this analysis shows that presence of bank management with integrity had a significant positive effect significant level on customer loyalty. This result means that the presence of bank management with integrity contributed significantly to bank customers' loyalty to their banks. In other words, customers were loyal to their banks because they could identify with, and were aware of, the good and proven character of the bank management team. This, amongst others, includes honesty, high moral standards, respect for customers, assisting customers and being frank to customers with regard to banking transactions. This culture of integrity, in turn, improved work environment and productivity. Customer trust is developed where an organisation's leadership has created a culture of integrity, which ultimately influences the quality of corporate governance system in the organisation. Individual-level integrity is associated with the character of a person who is consistently considerate, compassionate, transparent, honest and ethical (Duggar 2009). These characteristics create a relationship of trust with others because a person with integrity is considered reliable and predictable in satisfying the needs and requirements of others. Apart from trust, at a corporate level, leaders with integrity create a culture that provides reliability and predictable results (Duggar 2009). Similarly, considering the association and covariance between customer loyalty and bank management with integrity attributes, a positive relationship at significant level of $p=0.000$ was found in all cases. This result further confirmed the importance of these attributes in increasing customer loyalty to their banks.

The presence of competent management was found to have positive significant influence on customer loyalty. This result implies that the presence of competent bank management positively determined the extent to which customers were loyal to their banks. Customers remained loyal to their banks because they were able to identify a competent management team in their banks. Put differently, customers would not be loyal to their banks if they had observed incompetence amongst the management team. As with other organisations, previous studies suggest that companies with boards that are knowledgeable and experienced in financial matters are likely to issue fewer misleading disclosures to users of financial statements (Abbott, Parker \& Peters 2004; Donoher, Reed \& Storrud-Barnes 2007). Customer loyalty and all the attributes of competent bank management were also found to be positively correlated at a significant level, where 'responding to customer banking needs' was found to be highly associated with customer loyalty compared to others.

Furthermore, transparency or disclosure domain of corporate governance practices was found to negatively affect bank customers' loyalty. It can be inferred from this result that the 
transparency or disclosure domain of corporate governance practices in customers' banks was poor. It did not contribute positively to customers' loyalty status during the course of this study. This finding is inconsistent with that of Oki and Maimako (2015) who found a positive relationship between transparency, exhibited as the extent of disclosure, and performance of banks in Nigeria. Banking customers in Nigeria frequently complained about unauthorised charges by banks, camouflaged under various descriptions, such as 'management fees', 'processing fees', 'commission of turnover' and 'transfer telephone alert fees' to name a few (Modupe 2016). Therefore, customers did not view their banks' management transactions as transparent. This negative stance impaired their disposition to be loyal to their banks, which was attributable to other corporate governance practices, as revealed in this study.

Importantly, the cross-loading result of the covariance between customer loyalty and the attributes of transparency or disclosure domain confirmed that customers' accessibility to bank officials had the highest strength of association with customer loyalty, compared to other attributes, which confirmed the importance of openness and readiness to help customers in times of need. On the other hand, banks' provision of information on their contribution to the community had the weakest link to customer loyalty. Undeniably, customers will be more loyal to banks where staff members or officials always assist them when the need arises than in the banks where they are ignored or not assisted.

The extent to which a customer complaints management system influenced or affected customer loyalty was explained in this study. The study found that a customer complaints management system in banks had a positive and significant effect on customer loyalty. This result showed that customers are loyal, or remained loyal, to their banks because of the presence of a customer complaints management system where all their transaction queries and complaints were processed. The absence of this system could also lead to customers not being loyal to their banks, based on the identified attributes of loyalty. Further tests of covariance confirmed bank management's apology for customer complaints as the highest attribute of the complaint management domain, while fast resolution of complaints was found to be least associated with customer loyalty to banks. The practice of apologies made to customers can be explained in many ways. It is commonplace for bank customers to remain loyal to banks that take responsibility for their actions and revert with an apology in a timely fashion should transactional errors arise.

This study tested and found that corporate reputation garnered by banks over time positively affected customer loyalty to a bank at a very statistically significant level. Conventional wisdom suggests that if a bank's reputation is positive, then it can be assumed that its customers will also perceive its services positively, which should have an effect on customer loyalty. As such, customers' loyalty to their bank increased as customers recognise or are aware of bank officials and management's reputation. Notably, banks that were progressive and innovative in their transactions attracted more loyalty from their customers. This result from the present study corresponded with established findings in the literature. Ewing, Caruana and Loy (1999) evinced that strong corporate reputation is positively associated with successful organisational relationships with clients. In a similar vein, strong reputations have been found to have a positive impact on future financial performance (Eberl \& Schwaiger 2005; Robert \& Dowling 2002; Rose \& Thomsen 2004). These results, however, are in contradiction to the findings of Inglis, Morley and Sammut (2006) who did not establish any positive relationship between corporate reputation and performance. Importantly, the results from cross-loadings analysis confirmed that customer loyalty to banks had a higher association or covariance with banks' adaptability to positive changes. This means that banks' adaptability to positive changes in the industry increases customers' loyalty to their banks.

The result of correlation analysis strongly suggested that customer loyalty increases as each of the corporate governance practices (domains) increases, especially with the presence of competent bank management. This corroborates the findings from a study by Bebchuk, Cohen and Ferrel (2004), who investigated the relationship between corporate governance and organisational value. Their findings indicated that well-governed organisations show better performance.

\section{Conclusion}

Overall, this study indicated that all corporate governance practices had a positive effect on customer loyalty at a very significant level, except for transparency and disclosure, which had an inverse relationship and effect on customer loyalty. As such, any increase in the level of corporate governance practices in the bank, excluding the aspect of transparency and disclosure, will likely increase customer loyalty. This could be explained against the backdrop of the recent spate of bank failures in Nigeria and the subsequent reform process. Customers began to realise the importance of corporate governance in determining their banks' fidelity. Comparatively, the presence of competent management had the most notable effect on customer loyalty, followed by the presence of bank management with integrity. These results imply that customers will pledge their loyalty to banks with senior bank management that are considered skilled, knowledgeable and experienced in the banking business. Correlation analysis revealed that all corporate governance practices (domains) had a positive association with customer loyalty at statistically very significant level.

\section{Acknowledgements Competing interests}

The authors declare that they have no financial or personal relationships that may have inappropriately influenced them in writing this article. 


\section{Author's contributions}

Both authors have worked as a group. The participants were obtained from M.F.'s class, but both were present during the group interviews. The literature review was divided up into various tasks, which was undertaken by both authors.

\section{References}

Abbott, L.J., Parker, S. \& Peters, G.F., 2004, 'Audit committee characteristics and restatements. Auditing', A Journal of Practice \& Theory 23, 69-87. https://doi. org/10.2308/aud.2004.23.1.69

Adekoya, A., 2011, 'Corporate governance reforms in Nigeria: Challenges and suggested solutions', Journal of Business Systems, Governance and Ethics 6(1), 38-46.

Adeyemi, B., 2011, 'Bank failure in Nigeria: A consequence of capital inadequacy, lack of transparency and non-performing loans?', Banks and Bank Systems 6(1), 99-109.

Alrubaiee, L. \& Al-Naze, N., 2010, 'Investigate the impact of on relationship marketing orientation on customer loyalty: The customer's perspective', International Journal of Marketing Studies 2(1), 155-174. https://doi.org/10.5539/ijms. v2n1p155

Afsar, B., Rehman, Z.U., Qureshi, J.A. \& Shahjehan, A., 2010, 'Determinants of customer loyalty in the banking sector: The case of Pakistan', African Journal of Business Management 4(6), 1040-1047.

Bagozzi, R.P., Yi, Y. \& Philipps, L.W., 1991, 'Assessing construct validity in organisational research', Administrative Quarterly 36(1), 421-458. https://doi.org/10.2307/ 2393203

Bebchuk, L., Cohen, A. \& Ferrel, A. 2004, What matters in corporate governance? Working paper, Harvard Law School, Cambridge, MA

Black, B., Jang, H. \& Kim, W., 2006, 'Does corporate governance predict firms' market values? Evidence from the Korean market', Journal of Law, Economics and Organisation 22(1), 336-413.

Bloemer, J., Ruyter, K. \& Peeters, P. 1998. Investigating drivers of bank loyalty: The complex relationship between image, service quality and satisfaction, International Journal of Bank Marketing, 16(7):276-286.

Bobalca, C., 2014, 'Determinants of customer loyalty. A theoretical approach', Economy \& Business Journal 8(1), 995-1005

Brady, M.K., Knight, G.A., Cronin J. Jr, Toma, G., Hult, M. \& Keillor, B.D., 2005 'Removing the contextual lens: A multinational, multi-setting comparison of service evaluation models', Journal of Retailing 81(3), 215-230. https://doi. service evaluation models', Journal
org/10.1016/j.jretai.2005.07.005

Central Bank of Nigeria, 2006, Code of Corporate Governance for Banks in Nigeria Post Consolidation, Central Bank of Nigeria, Nigeria.

Chatterjee, S., Harrisson, J. \& Bergi, D., 2003, 'Failed takeover attempts, corporate governance and refocusing', Strategic Management Journal 24(1), 87-96.

Choudhary, K.V., 2015, 'Impact of board size on firm performance: A study of selected BSE 500 Companies', Journal of Management and Technology 10(1), 34-40.

Cronin, J.J., Brady, M.K. \& Hult, G.T.M., 2000, 'Assessing the effects of quality, value, and customer satisfaction on consumer behavioral intentions in service environments', Journal of Retailing 76(2), 193-218.

Donoher, W.J., Reed, R. \& Storrud-Barnes, S.F., 2007, 'Incentive alignment, control and the issue of misleading financial disclosures', Journal of Management 33(1), 547-569. https://doi.org/10.1177/0149206307302550

Duggar, J.W., 2009, 'The role of integrity in individual and effective corporate leadership', Journal of Academic and Business Ethics 3(1), 1-7.

Eberl, M. \& Schwaiger, M., 2005, 'Corporate reputation: Disentangling the effects on financial performance', European Journal of Marketing 39(7/8), 838-854. https:// doi.org/10.1108/03090560510601798

Esmaeilpour, M. \& Barjoei, S., 2016, 'The impact of corporate social responsibility and image on brand equity', Global Business and Management Research: An International Journal 8(3), 55-66.

Ewing, M., Caruana, A. \& Loy, E.R., 1999, 'Corporate reputation and perceived risk in professional engineering services', Corporate Communications 4(3), 121-128. professional engineering services', Corporate
https://doi.org/10.1108/13563289910288320

Fama, E.F. \& Jensen, M.C., 1983, 'Separation of ownership and control', Journal of Law and Economics 26(1), 301-325. https://doi.org/10.1086/467037

Fombrun, C.J., Gardberg, N.A. \& Sever, J.M., 2000, 'The reputation quotient: A multistakeholder measure of corporate reputation', The Journal of Brand Management 7(4), 241-255. https://doi.org/10.1057/bm.2000.10

Ghazizadeh, M., Besheli, A.S. \& Talebi, V., 2010, 'Assessing of bank customers retention and loyalty: A case study of state-owned banks in Tehran', European Journal of Social Sciences 17(2), 274-287.

Gladson, C., 2007, 'Effects of ownership structure on marketing goals attainment', in I.H. Harrisson (ed.), Corporate Governance, Springfield Publishers, Springfield, IL.

Gummesson, E., 1998, 'Productivity, quality and relationship marketing in service operations', International Journal of Contemporary Hospitality Management 10(1), 4-15. https://doi.org/10.1108/09596119810199282

Gummesson, E., 2014, 'Productivity, quality and relationship marketing in service operations: A revisit in a new service paradigm', International Journal of
Contemporary Hospitality Management 26(5), 656-662. https://doi.org/10.1108/ IJCHM-01-2014-0017

Hafiz, M.W.R., Muhammad, S., Naeem, S. \& Mehboob, A., 2015, 'Factors affecting customer loyalty in banking sector: A study on banks in Bahawalpur (Pakistan)', International Journal of Accounting and Financial Reporting 5(1), 239-254.

Hair, J.F., Ringle, C.M. \& Sarstedt, M., 2011, 'PLS-SEM: Indeed a silver bullet', Journal of Marketing Theory and Practice 19(1), 139-151. https://doi.org/10.2753/ MTP1069-6679190202

Hair, J.F.J., Hult, G.T.M., Ringle, C.M. \& Sarstedt, M., 2017, A primer on Partial Least Squares Structural Equation Modeling (PLS-SEM), 2nd edn., Sage, Thousand Oaks, CA.

Hawley, J.P., 1996, The rise of Fiduciary Capitalism: How institutional investors can make corporate America More Democratic, University of Pennsylvania Press, Philadelphia.

Ikeora, J.J.E., Igbodika, M.N. \& Andabai, P.W., 2016, 'Banking sector reforms and the performance of Nigerian economy: A vector error correction investigation (VECM)', European Journal of Research and Reflection in Management Sciences 4(2), 52-59.

Inglis, R., Morley, C. \& Sammut, P., 2006, 'Corporate reputation and organizational performance: An Australian study', Managerial Auditing Journal 21(9), 934-947. https://doi.org/10.1108/02686900610705028

Jones, G.R. \& George, J.M.,1994, Contemporary Management, 7th edn., McGraw-Hill, New York.

Kim, W.G. \& Brymer, R.A., 2011, 'The effects of ethical leadership on manager job satisfaction, commitment, behavioural outcomes and firm performance', satisfaction, commitment, behavioural outcomes and firm performance,
International Journal of Hospitality Management 30(4), 1020-1026. https://doi. International Journal of Hospitality
org/10.1016/j.ijhm.2011.03.008

Klaus, P. \& Maklan, S., 2013, 'Customer experience: Are we measuring the right things?', International Journal of Market Research 55(2), 227-246. https://doi. org/10.2501/IJMR-2013-021

Mehran, H., 1995, 'Executive compensation structure, ownership, and firm performance', Journal of Financial Economics 38(2), 163-184. https://doi.org/ 10.1016/0304-405X(94)00809-F

Modupe, A., 2016, 'Banking in Nigeria: Developments and customers' challenges', Keynote paper delivered by Adetokunbo Modupe, Chairman, TPT International at the fourth Brand Journalists' Association of Nigeria, (BJAN) Consumer Right Day the fourth

Muchemwa, M.R., Padia, N. \& Callaghan, C.W., 2016, 'Board composition, board size and financial performance of Johannesburg stock exchange companies', South African Journal of Economic and Management Sciences 19(4), 497-513. https:// African Journal of Economic and Mand
doi.org/10.4102/sajems.v19i4.1342

Myftaraj, E. \& Nexhipi, O., 2014, 'The importance of customer loyalty in relationship marketing in the onlime and offline market. The case of the Albanian financial sector', Indisciplinary Journal of Research and Development 1(2), 1-6.

Ngerebo, T.A. \& Sweneme, Y., 2012, 'The effects of corporate governance on patronage of banking services in Nigeria', Australian Journal of Business and Management Research 2(5), 30-36.

Nguyen, N. \& Gaston LeBlanc, G., 2001, 'Image and reputation of higher education institutions in students' retention decisions', International Journal of Educational Management 15(6), 303-311. https://doi.org/10.1108/EUM0000000005909

Obioha, O.O., 2017, 'An integrated framework for corporate governance practices and customer loyalty in the Nigeria retail banking sector', DTech thesis, Business School, Tshwane University of Technology.

Obiyo, O.C. \& Totbira, L.L., 2011, 'Corporate governance and firm performance in Nigeria', International Journal of Research in Commerce and Management 2(8), 19-31.

Ogbechie, C. \& Koufopoulos, D.N., 2010, Corporate governance and board practices in the Nigerian banking industry, viewed 04 March 2016, from www.cogbechie@ibs. edu.ng or Dimitrios@brunel.ac.uk.

Oki, E.U. \& Maimako, S.S., 2015, 'Corporate governance disclosure practices and bank performance in Nigeria: An empirical investigation', International Journal of Managerial Studies and Research 3(1), 49-56.

Oliver, R.L., 1999, 'Whence customer loyalty?', Journal of Marketing 63(1), 33-44. https://doi.org/10.2307/1252099

Parasuraman, A., Zeithaml, V.A. \& Berry, L.L., 1985, 'A conceptual model of service quality and its implications for future research', Journal of Marketing 14(Fall), 41-50. https://doi.org/10.2307/1251430

Peters, G.T. \& Bagshaw, K.T., 'Corporate governance mechanisms and financial performance of listed firms in Nigeria': A content analysis', Global Journal of Contemporary Research in Accounting, Auditing and Business Ethics (GJCRA) 1(2), 103-128.

Petruzzellis, L., Romanazzi, S. \& Gurrieri, A.R., 2009, 'Loyalty and customer satisfaction in retail banking: The role of social network', ESCP, 1-23.

Rai, A.K. \& Srivastava, M., 2012, 'Customer loyalty attributes: A perspective', NMIMS Management Review 22, 49-76.

Rashid, A., 2018, 'Board independence and firm performance: Evidence from Bangladesh', Future Business Journal 4(1), 34-49. https://doi.org/10.1016/j. fbj.2017.11.003

Roberts, P.W. \& Dowling, G.R., 2002, 'Corporate reputation and sustained superior financial performance', Strategic Management Journal 23(12), 1077-1093. https://doi.org/10.1002/smj.274

Rose, C. \& Thomsen, S., 2004, 'The impact of corporate reputation on performance: Some Danish evidence', European Management Journal 22(2), 201-210. https:// doi.org/10.1016/j.emj.2004.01.012 
Sanusi, J.O., 2002, 'Enhancing good corporate governance: A strategy for financial sector soundness', Keynote address delivered at the Annual Dinner of the sector soundness', Keynote address delivered at the Annual
Chartered Institute of Bankers of Nigeria at Abuja, 8th November.

Shen, C. \& Chih, H., 2007, 'Earnings management and corporate governance in Asia's emerging markets', Corporate Governance 15(5), 999-1021. https://doi.org/ $10.1111 / \mathrm{j} .1467-8683.2007 .00624 . x$

Suprenant, C.F. \& Solomon, M.R., 1987, 'Predictability and personalisation in the service encounter', Journal of Marketing 51(4), 86-96. https://doi.org/10.2307/ 1251131
Taleghani, M., Biabani, S., Gilianinia, S., Rahbarinia, S. \& Mousavian, S.J., 2011, 'The relationship between customer satisfaction and relationship marketing benefits', Arabian Journal of Business and Management Review 1(3), 78-85.

Weir, C. \& Laing, D., 2001, 'Governance structures, director independence and corporate performance in the UK', European Business Review 13(2), 86-95.

Zeithaml, V.A., 1981, 'How consumer evaluation processes differ between goods and services', in J.H. Donelly \& W.R. George (eds.), Marketing of services, pp. 186-190, American Marketing Association, Chicago, IL. 